\title{
Computational Verification of the NBR 15.220- 3 Recommendations for Thermal Comfort in the City of Curitiba
}

\section{Mariana Ribeiro Martins ${ }^{1}$}

https://orcid.org/0000-0002-1972-1065

\author{
Aloísio Schmid ${ }^{1}$ \\ https://orcid.org/0000-0003-2737-6246 \\ 1 Universidade Federal do Paraná; Curitiba, Paraná, Brazil \\ Received: 2018.11.05; Accepted: 2019.07.26. \\ * Correspondence: mariana@ghome.com.br; aloisio.schmid@gmail.com; Tel.: M.M. +55 41 \\ 33087178; A.S. +55 4133613069
}

\section{HIGHLIGHTS}

- Simulation to confirm applicability of Thermal Mass Strategy

- Brazilian Standard for Thermal Performance was not validated.

\begin{abstract}
:
The Brazilian Standard for Thermal Performance and Bioclimatic Zoning (NBR 15.220-3) establishes twelve strategies to achieve thermal comfort inside buildings considering the dry bulb temperature and the predominant humidity in each climate. These strategies are visualized in the Bioclimatic Charts of Brazil main cities. This study seeks, through computational simulation by the EnergyPlus software, to test the bioclimatic strategy proposed by the Standard for the city of Curitiba through the addition of thermal mass. The goal is to check the validity of the temperature limits related to the constructive guidelines described. The article is restricted to the analysis of Bioclimatic Zone 01 in which Curitiba is inserted. To this end, the unit of analysis was a standard apartment located in the city. It was used as a model for simulations with constructive materials of different thicknesses and thermal properties. The indexes of the materials correspond to those described in the Standard. From the comparison of results of the buildings internal temperature regarding the external temperature data, the applicability of the Thermal Mass Addition strategy was verified in the gap between 14 to 21 degrees Celsius of Dry Bulb Temperature. In conclusion, the limits stipulated in Standard for this Area were only partially confirmed.
\end{abstract}

Keywords: Bioclimatic Chart. NBR 15.220-3. Thermal Mass Zone, thermal performance. 


\section{INTRODUCTION}

It is natural for human beings, in a situation of rest, to quest the sensation of comfort and, also in other activities, for thermal comfort. Even instinctively, humans seeks to keep themselves protected from the weather and abrupt variations in temperature. Over time, mechanisms such as clothing and shelters have been developed to mitigate such variations.

Through the enforcement of adequate architectural design to the local climate and the adoption of coherent materials it is possible to achieve a large part of the need for thermal comfort with minimal, if not zero, energy expense for air conditioning.

Thus, passive architecture is the subject of Baruch Givoni, a pioneer of the study of thermal comfort in warm climates. Among its production, the Bioclimatic Chart, presented in 1992, is one of the main references for the bioclimatic project applied in Brazil [1]. The Chart, also called Bioclimatic Diagram, is used as the basis for the current Standards regarding thermal performance of buildings in the country. The referred norm, NBR 15.220, establishes guidelines for each defined bioclimatic zone in Brazil seeking to achieve thermal comfort inside buildings.

From this Norm it is possible to explain the design strategies for warm climates by the aforementioned work by Givoni [1]. However, for design strategies in cold climates that appear in the Standard is not obvious its grounding.

The city of Curitiba, object of this research, is in the Bioclimatic Zone 01 [2]. This is a particular zone in which only twelve cities are included. Those cities have mild weather for much part of the year, which differs from most parts of the rest of the country that are usually warmer.

Its particular climatic situation in relation to the rest of Brazilian climates and bioclimatic zones presents challenges for local urbanists and there are few reference points in the national technical-scientific literature. [3]

\section{MATERIAL AND METHODS}

Through computer simulation in the EnergyPlus software version 8.3, using as a unit of analysis a standard apartment of approximately $70 \mathrm{~m}^{2}$ of exclusive residential use, the temperature limits for the addition of thermal mass proposed by the Bioclimatic Chart of NBR 15.220-3 were verified, based on the climate data of Curitiba.

Figure 1- Apartment - $0^{\circ}$ Orientation

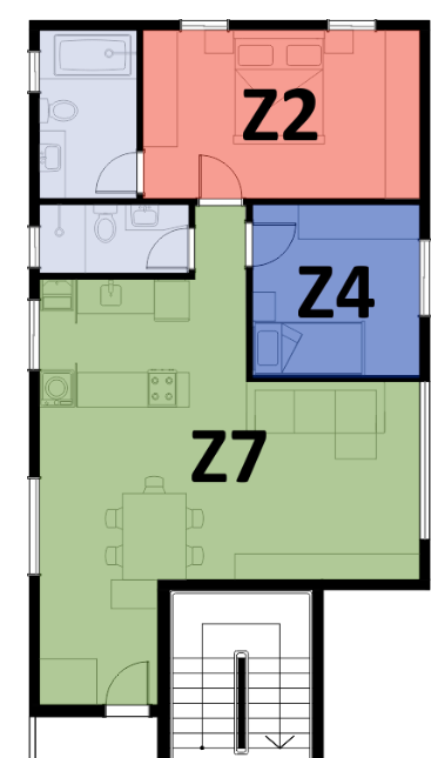


The software was chosen because it was validated by ASHRAE Standard 140, as stipulated by the Norm [4].

The apartment has the following rooms: entrance hall, living and dining rooms, kitchen, laundry, double bedroom, single bedroom and bathrooms, arranged according to Figure 1. For simulation purposes they were grouped as follows: Z7: Entrance Hall, Living and Dining Rooms, Kitchen, Laundry; Z2: Double Bedroom; Z4: Single Bedroom. The bathrooms were disconsidered in the simulation because for the most of the time they are not occupied. (Figure 1)

Also, to better interpret the data, the ceiling, the floor and the wall next to the common area of the building were considered adiabatic.

Considering that solar orientation is the recommended strategy for lower temperatures $\left(10.5^{\circ} \mathrm{C}\right.$ to $\left.14^{\circ} \mathrm{C}\right)$, the apartment was initially simulated considering the $0^{\circ}, 90^{\circ}, 180^{\circ}$ and $270^{\circ}$ orientations of the main facade with same internal masonry wall of $12 \mathrm{~cm}$. The $0^{\circ}$ orientation was the one that provided comfort for the greatest number of hours during the year.

With the result obtained from the best performance, the material and thickness of the internal walls, which represent the thermal mass, were varied in order to ascertain their effect on the internal temperature of the building. It was evaluated a traditional masonry of 12 and $15 \mathrm{~cm}$ thickness, dry-wall of 7 and $10 \mathrm{~cm}$ thickness with and without rock wool.

In the masonry the change was about the size of the brick. The $12 \mathrm{~cm}$ mansory wall was built with $9 \mathrm{~cm}$ brick and in the $15 \mathrm{~cm}$ thick mansory wall with the $12 \mathrm{~cm}$ brick. On the dry-walls only the internal space filled with air was altered.

\section{Climate Data}

The database for the climatic conditions was extracted from INPE (National Institute of Space Research). The data collection point is at Afonso Pena Airport, located in the city of São José dos Pinhais, metropolitan region of Curitiba. Data was entered into the EnergyPlus program using the database contained in the software site itself. [5] [6]

The average value of the relative air humidity index in Curitiba, according to historical data, was $81.19 \%$ considering the period between 1961 and 2016 and, as a simplification of the data, it was adopted the humidity of $80 \%$. Therefore, for all the graphs shown in this study, relative air humidity was considered $80 \%$, including in comparison with the temperature limits established by the Diagram.

\section{User Data}

Heat generators in buildings are considered to be people (users), lighting and electrical equipment. The values adopted in this simulations look for to represent a generic behavior, not inferring to a certain public the use of this housing unit.

It is considered that four people live at this apartment and are distributed equally, which results in approximately $17.5 \mathrm{~m}^{2} /$ person. The occupation considered was that all residents are in place between 6:00 pm and 9:00 am the following day in rest or sleeping activities. Between 9:00 am and 12:00 pm only one person occupies the apartment. At lunchtime, between 12:00 noon and 1:30 pm, three people remain at the apartment. Between 1:30 pm and 6:00 p.m., two people stay at the apartment and this is repeated daily, including weekends.

The ventilation is considered uninterrupted with the adopted value of 0.25 air changes per hour.

The lighting adopted in the model had energy consumption of $10 \mathrm{~W} / \mathrm{m}^{2}$ and it was only used from the period of 5:00 pm until midnight, daily. The same rate/ area was considered for the electrical equipment, but the use is distributed differently, considering intermittent use.

The behavior of users was kept constant, therefore the results vary only in relation to the constructive materials. The desired result of the research, which is to evaluate the effect of adding thermal mass to the internal walls of the apartment, is thus affirmed. 


\section{Construction Material Data}

The constructive systems considered on the internal walls were only two: traditional masonry and dry-wall. In the case of dry-wall two options were simulated: the first with only air between the two panels and the second with the use of a rock wool inside the panels. The goal was to simulate real conditions, since this material (rock wool) is often applied to drywalls functioning as a bulkhead with acoustic function.

The properties of the materials were defined as reference in the same NBR 15.220 (Table 1) for application in the simulated models.

Table 1: Thermal Property of the materials applied

\begin{tabular}{|c|c|c|c|c|c|}
\hline Material & $\begin{array}{l}\text { Thickness. } \\
\text { (cm) }\end{array}$ & $\begin{array}{c}\text { Thermal } \\
\text { Conductivit } \\
y \\
(\mathrm{~W} / \mathrm{mK})\end{array}$ & $\begin{array}{c}\text { Specific } \\
\text { Mass } \\
\left(\mathrm{kg} / \mathrm{m}^{3}\right)\end{array}$ & $\begin{array}{c}\text { Specific } \\
\text { heat. } \\
(\mathrm{J} / \mathrm{kgK})\end{array}$ & $\begin{array}{c}\text { Solar } \\
\text { absorption }\end{array}$ \\
\hline Mortar & 1.5 & 1.15 & 2000 & 1000 & 0.01 \\
\hline Concrete & 12 & 1.75 & 2300 & 1000 & 0.01 \\
\hline Wood & 3.5 & 0.14 & 600 & 2300 & 0.01 \\
\hline $\begin{array}{c}\text { Brick - } 9 \\
\text { holes }\end{array}$ & 12 & 0.90 & 1500 & 920 & 0.01 \\
\hline $\begin{array}{c}\text { Brick- } 6 \\
\text { holes }\end{array}$ & 9 & 0.90 & 1500 & 920 & 0.01 \\
\hline $\begin{array}{l}\text { Plaster (dry- } \\
\text { wall) }\end{array}$ & 1.5 & 0.60 & 1500 & 1000 & 0.01 \\
\hline Rock Wool & 3.5 & $\begin{array}{c}0.04 \\
\text { Source: NBR } 15.2\end{array}$ & $\begin{array}{c}50 \\
-2, \text { ABNT, } 2\end{array}$ & 1000 & - \\
\hline
\end{tabular}

\section{RESULTS}

Simulations were held for the full year and were recorded in hourly spreadsheets and organized by monthly averages. The choice was made by following the form of representation adopted by the Norm (monthly). The results were rearranged in ascending order of the dry bulb temperature of the external air, so that it can be observed from which external temperature, both lower and upper limits, the thermal comfort inside the building is reached.

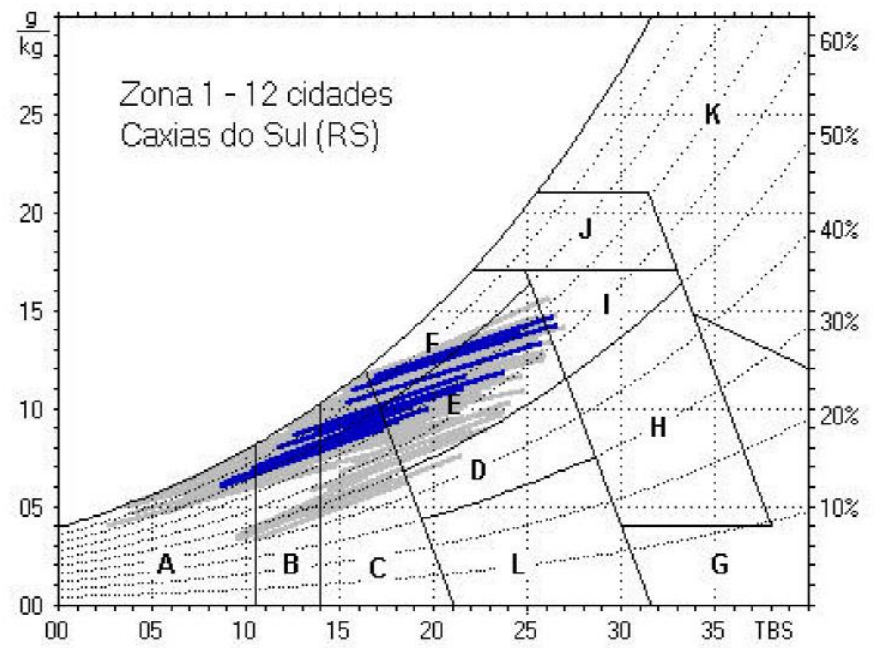

Figure 2- Adapted Bioclimatic chart of the bioclimatic zone 01

Source: Adapted from ABNT (2005)

Results of the internal temperatures of the building were compared to that expected in the Thermal Comfort Zone, in which all graphs is represented by the green hatched region. The values considered are in the range of $17^{\circ} \mathrm{C}$ and $25^{\circ} \mathrm{C}$, as the Norm establishes [2]. 
The aim of using the recommended strategies is to make internal air, in its daily average, remain within the limits of thermal comfort for as many hours as possible.

The thermal mass zone considered for the analysis is one of the bioclimatic strategies recommended for Bioclimatic Zone 01, in which Curitiba is inserted. And therefore to the city, the following five strategies are determined, as shown in Figure 2: Artificial Heating Zone, where the use of artificial heating is necessary, represented by the letter "A"; Solar Heating Zone, represented by letter "B", where the shape, orientation and implantation of the building, besides the correct orientation of the glazed surfaces, can contribute to improve its heating in the cold period by solar radiation; Thermal Mass Zone for Heating, with the adoption of massive internal walls represented by the letter "C"; the dehumidification zone, where the renovation of internal air by ventilation helps in the feeling of comfort, this, represented by the letter "F". For this article, only simulations related to the thermal mass addition strategy for heating were carried out.

The meaning of the blue lines in Figure 2 are the interval, in each month, between the average daily minimum to the average daily maximum temperature. The standard considers for each line that the lenght fraction over each zone corresponds to the fraction of time at that situation, and defines the strategy (A through $L$ ) by yearly averages of those fractions.

Graphs 1 through 6 represent the montlhy average temperatures (red lines) organized from lowest to the highest. Resulting indoor temperatures are plotted in the brown, orange and cyan lines.

\section{Thermal Mass Zone for Heating}

The Thermal Mass Zone for heating, according to NBR 15.220, is that between dry bulb temperatures of $14^{\circ} \mathrm{C}$ to $17^{\circ} \mathrm{C}$ under relative humidity of $80 \%$ (Figure 2). For this simulation the characteristics of the external wall and ceiling were maintained, but the characteristics of the internal walls were altered. In the simulation of the apartment with addition of mass in the internal walls were adopted as materials those of traditional masonry (clay hollow bricks) and dry-wall (plasterboard).

In the case of simulation with walls in traditional masonry, the thermal performance of the internal wall of $12 \mathrm{~cm}$ was compared with that of $15 \mathrm{~cm}$. The dimensions were kept within a normality pattern because it is understood that the excessive addition of mass on the internal walls could result in an overload of the building structure and therefore would not be financially viable.

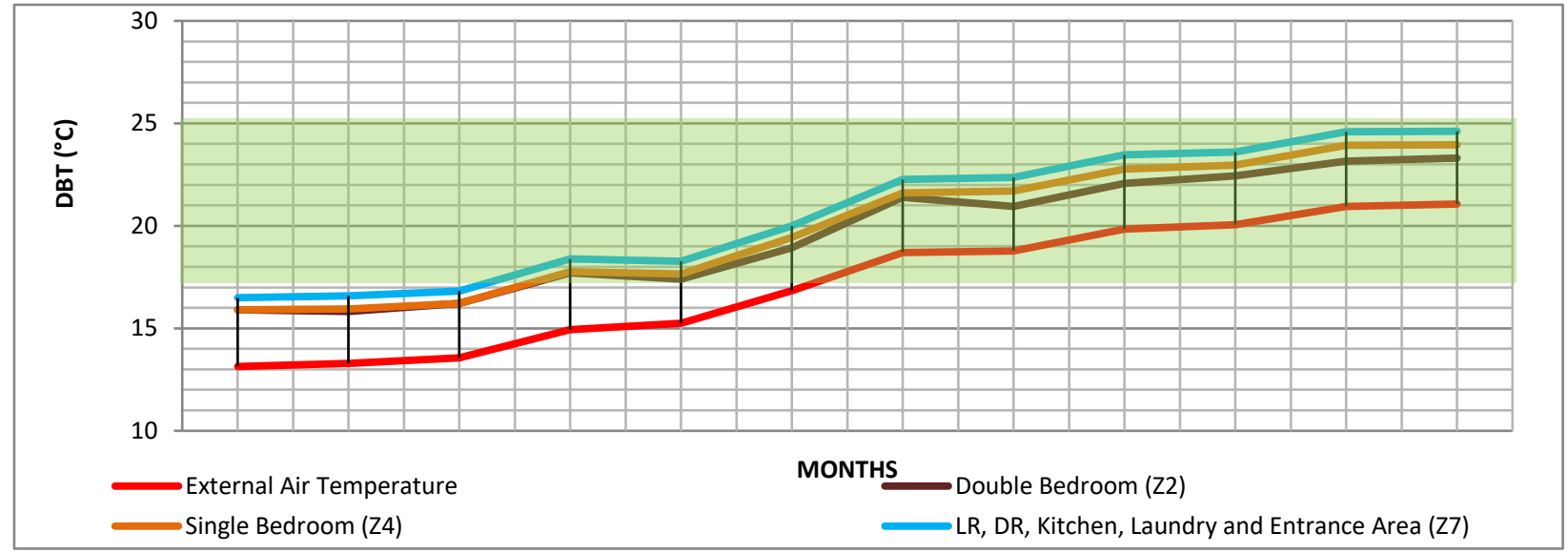

Graph 1- Monthly average temperatures of the building with $12 \mathrm{~cm}$ mansory internal wall and $0^{\circ}$ orientation

In the simulation of traditional masonry with a total thickness of $12 \mathrm{~cm}$, thermal comfort was obtained for external air temperatures greater than $14.25^{\circ} \mathrm{C}$ (Graph 1). In the simulation for internal masonry of $15 \mathrm{~cm}$ (Graph 2), comfort was reached when the external air 
temperature was $14.50^{\circ} \mathrm{C}$. In both, upper limit was not found, because even under the highest average monthly temperature $\left(21^{\circ} \mathrm{C}\right)$ the comfort range was not exceeded.

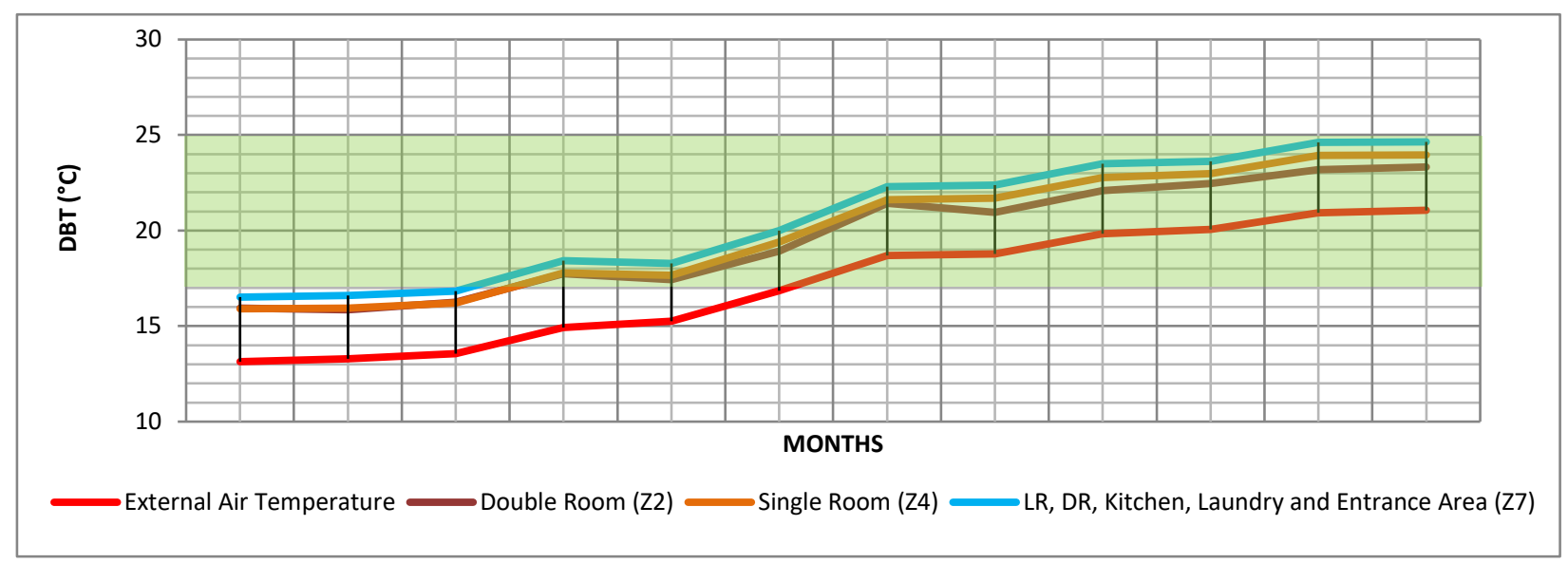

Graph 2- Monthly average temperatures of the building with $15 \mathrm{~cm}$ mansory internal wall and $0^{\circ}$ orientation

What has been verified, therefore, is that the addition of mass $(3 \mathrm{~cm})$ of the internal masonry had little influence on the result, and even with the wall of $12 \mathrm{~cm}$, thermal comfort in the internal space was reached in the areas of permanence with external DBT of $14,25^{\circ}$ $\mathrm{C}$ monthly average, when simulated with $0^{\circ}$ orientation, therefore approximately within the range expected by the Diagram. (Figure 2)

For the second simulation performed for this Zone material and wall thickness were changed. Following the same concept of adding thermal mass for heating, that is, increasing the mass of internal walls in order to increase thermal inertia, was considered for the second set of simulations the dry-wall construction. The thicknesses simulated were of $7 \mathrm{~cm}$ (Graph 3) and $10 \mathrm{~cm}$ (Graph 4).

Unlike the masonry simulation, the dry-wall simulation at $Z 7$ achieved a slight temperature range above the Thermal Comfort Zone. This indicates that the adoption of drywalls with thicknesses greater than $10 \mathrm{~cm}$ exceeds the thermal comfort range considered $\left(25^{\circ} \mathrm{C}\right)$.

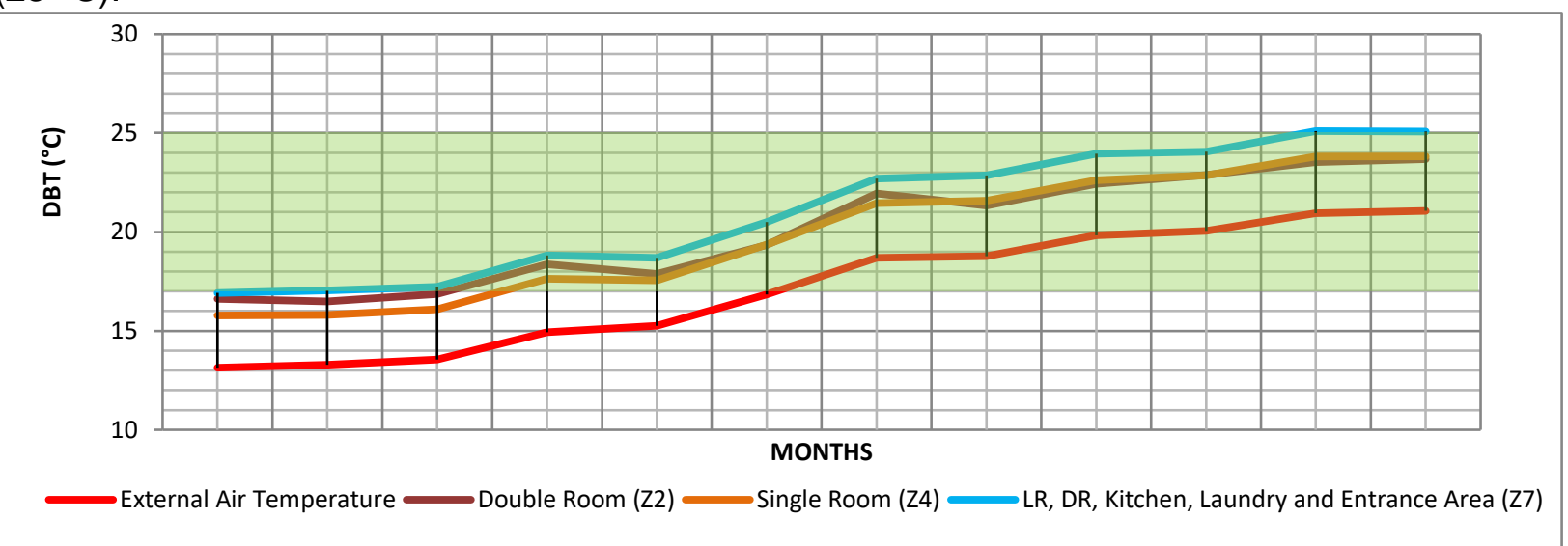

Graph 3 - Monthly average temperatures of the building with $7 \mathrm{~cm}$ internal dry-wall and $0^{\circ}$ orientation 


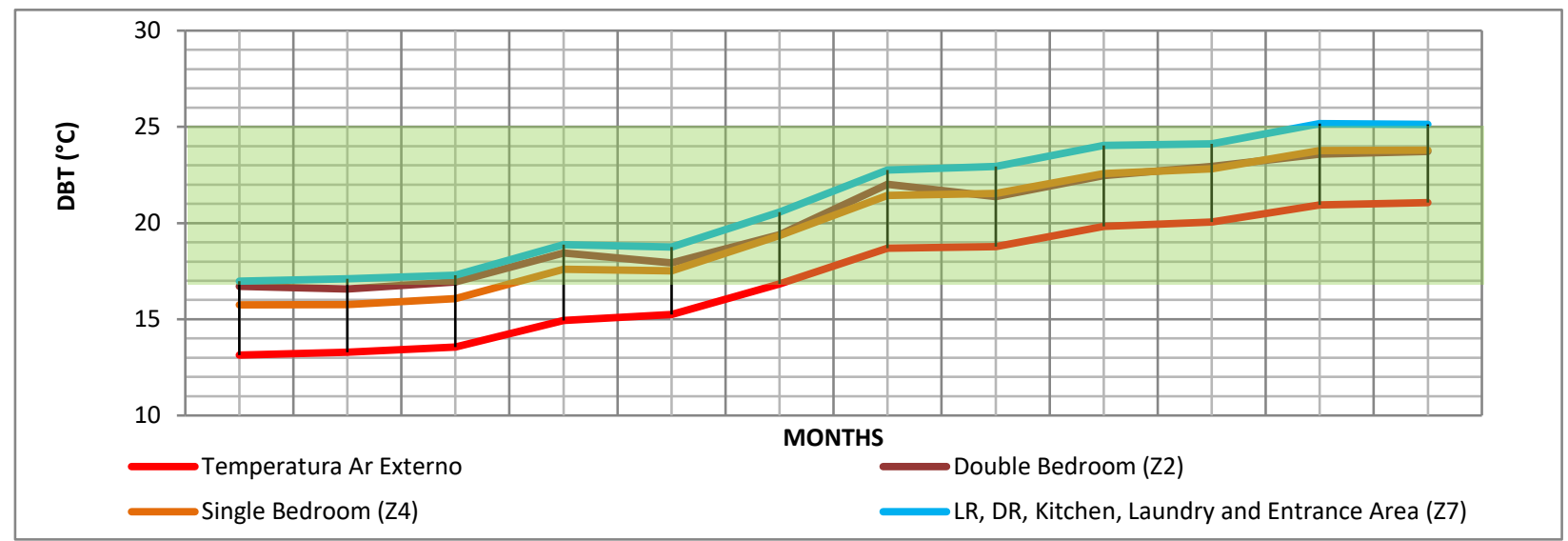

Graph 4 - Monthly average temperatures of the building with $10 \mathrm{~cm}$ internal dry-wall and $0^{\circ}$ orientation

A third simulation group was made. The dry-walls were simulated with the inner cavity filled with rockwool. The mass and total thickness of the inner walls were maintained. The main function of the rock wool is acoustic, but some result was obtained in the thermal comfort due to this material, as shown in Graph 5, for the $7 \mathrm{~cm}$ thickness wall and Graph 6, for the $10 \mathrm{~cm}$ thickness wall. A possible explanation is that there is a better insulation to the non-conditioned environments like the bathrooms.

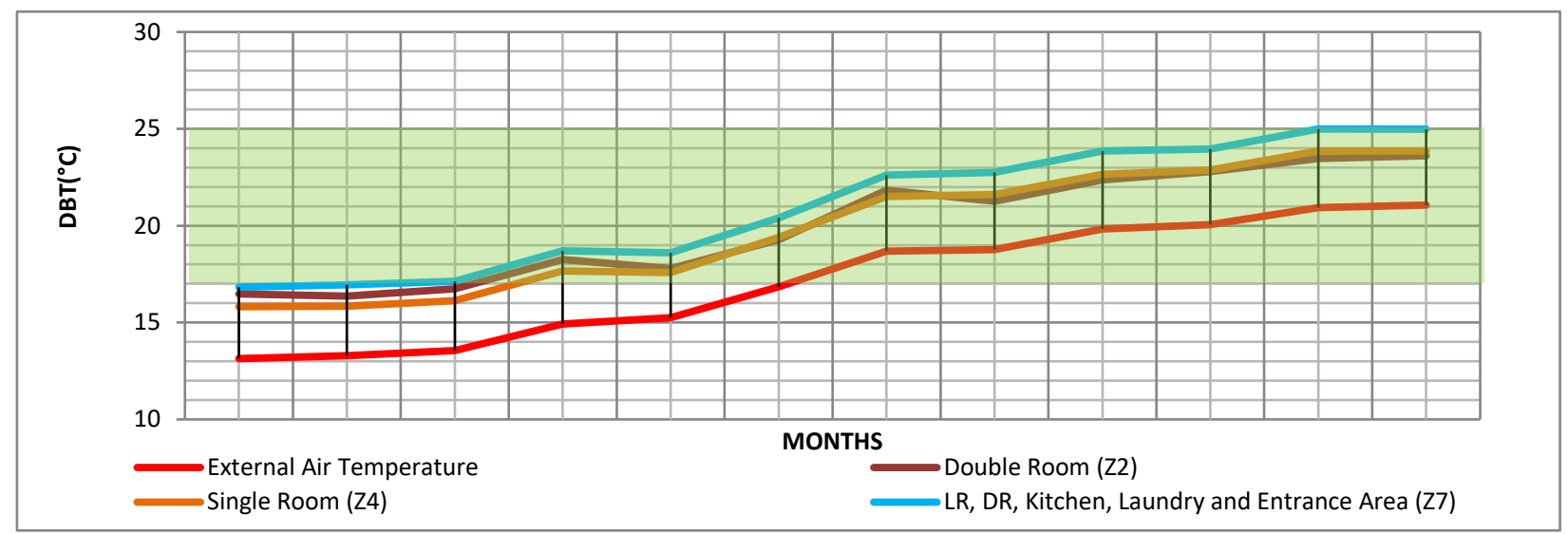

Graph 5 - Monthly average temperatures of the building with $7 \mathrm{~cm}$ internal dry-wall filled with rockwool and $0^{\circ}$ orientation

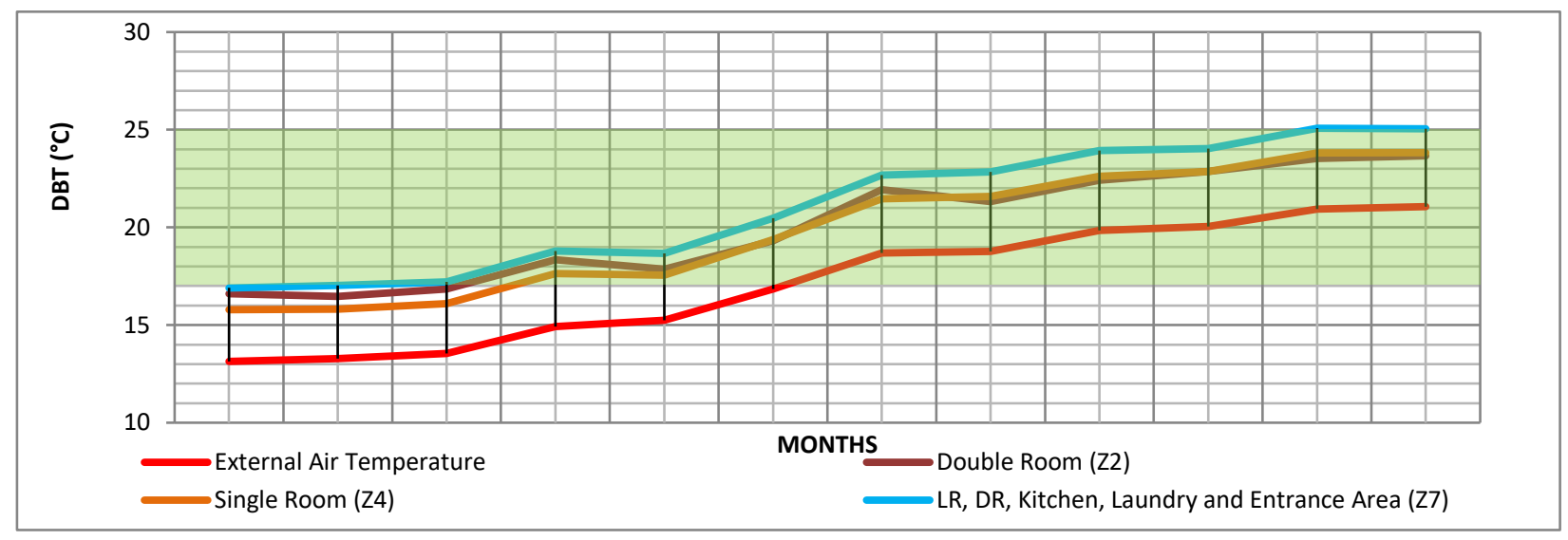

Graph 6 - Monthly average temperatures of the building with $10 \mathrm{~cm}$ internal dry-wall filled with rockwool and $0^{\circ}$ orientation 
When comparing the results for the $\mathrm{Z7}$ (Entrance hall, living and dining rooms and kitchen) with dry-walls with $7 \mathrm{~cm}$ and $10 \mathrm{~cm}$ both filled with rock wool values to other simulations were found, which indicates that the addition of $3 \mathrm{~cm}$ of rock wool has no relevant influence on thermal inertia. In average, the temperature difference with the addition of the $3 \mathrm{~cm}$ wall is $0.08^{\circ} \mathrm{C}$.

The same can be inferred between the difference in the addition of rock wool to each thickness. The presence or absence of wool incurs an average difference of only $0.09{ }^{\circ} \mathrm{C}$ for the two thicknesses.

The range of Mass Zone for Thermal Heating described in the Norm, therefore is only partially verified. The summary table of results shows that the maximum limit does not apply to the simulated wall thickness since the stipulated in the Diagram is $17^{\circ} \mathrm{C}$ to $80 \%$ humidity, as considered in this work (Table 2).

Table 2 - Upper and Lower Limits for the Thermal Mass Zone

\begin{tabular}{cccc}
\hline Construction & $\begin{array}{c}\text { Total Wall } \\
\text { Thickness } \\
(\mathbf{c m})\end{array}$ & $\begin{array}{c}\text { Lower } \\
\text { Limit }\left({ }^{\circ} \mathbf{C}\right)\end{array}$ & Upper Limit $\left({ }^{\circ} \mathbf{C}\right)$ \\
\hline Traditional Mansory & 12 & 14.25 & Not conclusive \\
Traditional Mansory & 15 & 14.50 & Not conclusive \\
Dry-wall & 7 & 14.50 & 21 \\
Dry-wall & 10 & 14.50 & 21 \\
Dry-wall filled with rockwool & 7 & 14.25 & 21 \\
Dry-wall filled with rockwool & 10 & 14.25 & 20.75 \\
& Source: Author & & \\
\hline
\end{tabular}

\section{DISCUSSION}

Internal temperature results were evaluated in comparison to the temperatures expected by the Bioclimatic Diagram established by the Norm. The limits found in the simulation were different from those expected. The addition of thermal mass, as recommended by the Norm, was not effective.

The thermal properties of the materials are the major influence in the simulated models. It should be noted, however, that the values considered may have imprecision. This is due the wide range that the Standard establishes for each material property and also regarding the lack of information of properties by the manufacturers.

Parallel to this, heat generators and ventilation that were considered equally for all models may have influenced the outcome. According to Balvedi (2018), the occupation of long-stay environments can be highlighted by its influence on thermal performance, since in addition to affecting the internal thermal load, occupation is conditional on keeping the windows open, for example. That is, the occupation influences significantly the thermal performance of the building.

\section{CONCLUSION}

The conclusion of this analysis is that the addition of thermal mass within real parameters did not result in a significant difference of the building thermal performance as indicated by NBR 15.220-3, since all the results were similar. The average difference between all materials is only $0.12^{\circ} \mathrm{C}$.

The greatest difference observed in the results is between the use of traditional masonry and drywall, and it is possible to conclude that the use of drywall on the internal area of the simulated model proved to be more adequate than traditional masonry, even if simulated with a thicker wall. Here, the significant difference in mass between dry-wall and masonry is emphasized. The dry-wall is approximately four times lighter than masonry. 
The best results obtained in the simulations were for the construction with external light wall, isolated light cover and internal walls of dry-wall with the cavity filled with rock wool and total wall thickness of $7 \mathrm{~cm}$.

What is observed, however, is that for most of the year the average monthly air temperature of the building is within the Thermal Comfort Zone. Only between June and August the temperature is below the lower limit of comfort $\left(17^{\circ} \mathrm{C}\right)$ and still does not reach the average of $15^{\circ} \mathrm{C}$. The small internal temperature difference between all simulated building types indicates that the use of 12 and $15 \mathrm{~cm}$ walls of masonry or 7 and $10 \mathrm{~cm}$ of dry-wall with or without rock wool are suitable for Bioclimatic Zone 01, using as the basis of the study the city of Curitiba.

The most relevant aspect of the conclusion is that the building, with light external walls and insulated light cover [2], has sufficient thermal capacity to be characterized as within the zone of thermal mass for heating, not relying on heavy or light internal walls. This is contrary to the recommendation of standard NBR 15.220 of "massive inner walls" for Bioclimatic Zone 01.

Funding: This research received no external funding

Acknowledgments: The authors thank the Civil Construction Masters of UFPR for the opportunity to develop this research.

Conflicts of Interest: "The authors declare no conflict of interest."

\section{REFERENCES}

1. Baruch Givoni. Comfort, climate analysis and building design guidelines. Energy and buildings, 1992 v.18: p. 11-23.

2. Associação Brasileira de Normas Técnicas. NBR 15220-3. Desempenho térmico de edificaçõesparte 3: Zoneamento Bioclimático Brasileiro e Diretrizes Construtivas para Habitações Unifamiliares de Interesse Social. 2005

3. Eduardo Leite Kruger et al. Calibração do índice de conforto para espaços externos physiological equivalent temperature (pet) para curitiba. Ambiente construído, Porto Alegre , v.18, n. 3, p.135-148, sept. 2018.

4. Associação Brasileira de Normas Técnicas. NBR 15575-1. Edificações habitacionais desempenho parte 1: requisitos gerais. 2013

5. Associação Brasileira de Normas Técnicas. NBR 15575-4. Edificações habitacionais desempenho parte 4: requisitos para os sistemas de vedações verticais internas e externas. 2013

6. Instituto Nacional de Meteorologia. Banco de dados de temperatura e umidade. Available at: http://www.inmet.gov.br/portal/index.php?r=clima/. Inmet, 2018. Acessed in march, 2018.

7. U.S. Department of Energy. Energy plus, v.8.3 weather data. Available at https://energyplus.net/weather-location/south_america_wmo_region_3/bra//bra_curitibaafonso.pen.838400_swera, 2016

8. Bruna Faitão Balvedi et al. Identificação de perfis de comportamento do usuário para edificações residenciais multifamiliares e naturalmente ventiladas em florianópolis. Ambiente construído, Porto Alegre, v. 18, n. 3, p. 149-160, sept. 2018. 